\title{
Feed formulation problem in Nigerian poultry farms: a mathematical programming approach
}

\author{
*V.O. Oladokun and A. Johnson
}

\author{
Department of Industrial and Production Engineering University of Ibadan, Ibadan, Nigeria \\ *vo.oladokun@mail.ui.edu.ng; +2348033919050
}

\begin{abstract}
The poultry industry has a significant effect on national economy; it is a popular industry for the small holders with tremendous contribution to GDP and employment creation. Poultry feed cost represents over $70 \%$ of the total cost of egg and broiler production, consequently efficient feed formulation practice is required for a sustainable poultry industry. Many Nigerian poultry farmers, however, employ inefficient methods like rule of thumb, experiences, and intuition to handle feed formulation problem. The aim of this study was to develop an optimization feed formulation model, using locally available feed ingredients, for the Nigerian poultry industry. Relevant literature was consulted to gather information on the practices prevalent in the industry, nutrient contents and availability of feed ingredients and their prevalent market prices. The decision variables, objective function and problem constraints were defined and a mathematical model of the feed formulation problem was developed and parameterized using data from a typical commercial farm. Model solution and post-optimality analysis results were obtained and compared with existing practice of the case study farm. Thirteen (13) decision variables and fourteen (14) constraints were identified. The optimal solution of the linear programming model gives $9 \%$ reduction in feed formulation costs compared to the existing method on the farm. Post optimality analysis also gave useful insight into the impact of changes in costs of feed inputs. The model will be very useful in poultry farm management in Nigeria.
\end{abstract}

Keywords: Poultry, Feed, Formulation, Linear Programming, Sensitivity analysis

\section{INTRODUCTION}

The poultry has become a popular industry for the small holders with tremendous contribution to Nigeria GDP and employment opportunities creation (Adebayo and Adeola, 2005; Okonkwo and Akubo, 2001). It is therefore important that poultry farming be carried out efficiently for high productivity and sustainability of the industry in Nigeria. It has been established that feeding constitutes over $70 \%$ of the total cost of egg and broiler production (Afolayan and Afolayan, 2008) which implies that efforts to increase poultry industry productivity should be directed towards improving feed formulation system. This paper seeks to apply mathematical optimization techniques to the feed formulation problem of the typical Nigerian poultry farm using locally available feed ingredients.

Some of the common techniques employed in feed formulation include The Pearson Square method, Linear Programming, Non Linear Programming, and Trial and Error method. The Person Square Method is a simple, well established and popular method of determining the correct proportions of two feed ingredients necessary to obtain a desired level of a particular nutrient. The method is most often used for protein. The method permits substitution of feed ingredients without disturbing the desired protein content of the diet. It is also used for some other nutrients like amino acids. Linear programming is the common method of Least Cost Feed Formulation which compares the nutrients required by the animal to the nutrients supplied by the available feed ingredients, and combines them to obtain a balanced diet at the least possible cost. Other quantitative techniques include genetic algorithm (Sahman et al, 2009), Multi-criteria modeling (Castrodeza et al, 2005) and Goal programming (Dogan et al, 2000). However Trial and Error method is the most popular method of formulating rations for poultry in Nigeria. As the name implies, the formulation is manipulated until the nutrient requirements of the birds is arrived at.

Components of Poultry Diets: Poultry diets are made primarily from a mixture of several feedstuffs 
such as cereal grains, soybean meal, animal byproduct meals, fats, and vitamin and mineral premixes (Longe, 1984; Alimon and Hair-Bejo, 1995). A poultry diet is expected to contain three essential nutrients of protein, vitamins, and minerals as well as provides adequate metabolizable energy (ME). Energy is very critical in poultry feed, in fact, the more the energy loaded in the ration, the less feed the birds would consume (Larbeir and Leclercq, 1994). The most easily available sources of energy are the carbohydrates contained in common grains, grain byproducts and plants generally. Most of the carbohydrate in poultry diets is provided by cereal grains. Suitable quantities of fat may be added to increase dietary energy concentrations and palatability.

Protein is essential in all animal life. Proteins make up a large part of the muscle, skin, beak, feathers, cartilage and internal organs of animals and are needed for growth, egg production, reproduction, production of antibodies to fight diseases, etc. The dietary requirement for protein is actually a requirement for amino acids. Specific amino acids must be provided in proper amounts and in some definite ratios to others. An undersupply of a single essential amino acid will inhibit the responses to those in adequate supply (Alimon and Hair-Bejo, 1995; Fanatico, 2010). In any protein, the limiting amino acid is the one which is below the standard.
For poultry, methionine is usually the first limiting amino acid and lysine the second limiting amino acid.

Since protein is not stored in the body to any considerable extent, any protein consumed above the birds' requirement is oxidized for energy. However, since protein sources are expensive and uneconomic for energy provision protein levels are usually stated in precise terms to be closer to the minimum requirement than other nutrients. Protein sources can be of a plant origin such as soya and groundnut cake or of an animal origin, such as fish meal and blood meal. Some sources of minerals include Oyster shell and limestone which are both rich in calcium. Bonemeal is a very good source of both calcium and phosphorus amongst others. Common salt can satisfy the birds' sodium and chloride requirements. However trace mineral requirements are usually met by supplementation via the vitamin/mineral premix (Scheideler, 2009).

Expected nutrient requirements, recommended allowances and ultimately feed specifications are available from many sources like sets of tables published by the American National Research Council (NRC) in 1994. For this study we adopted data shown table 1 sourced from a guide by Moreson (1998) with regard to the production aim.

\section{Table 1: Table showing the nutrient requirements with regard to production aims}

\begin{tabular}{|l|l|l|l|l|l|l|l|l|}
\hline & $\begin{array}{l}\text { Protein } \\
\text { Min. \% }\end{array}$ & $\begin{array}{l}\text { Fat } \\
\text { Min. } \\
\%\end{array}$ & $\begin{array}{l}\text { Fibre } \\
\text { Min. \% }\end{array}$ & $\begin{array}{l}\text { Calcium } \\
\text { Exact }\end{array}$ & $\begin{array}{l}\text { Phosphorus } \\
\text { Available }\end{array}$ & $\begin{array}{l}\text { Lysine } \\
\text { Min. \% }\end{array}$ & $\begin{array}{l}\text { Methionine } \\
\text { Min. \% }\end{array}$ & $\begin{array}{l}\text { M.E } \\
\text { Kcal/kg }\end{array}$ \\
\hline Chicks mash & 20.0 & 3.5 & 5.0 & 1.0 & 0.45 & 1.0 & 0.40 & 2640 \\
\hline $\begin{array}{l}\text { Grower's } \\
\text { mash }\end{array}$ & 16.0 & 3.5 & 7.5 & 1.0 & 0.35 & 0.80 & 0.27 & 2475 \\
\hline Layers mash & 16.5 & 3.7 & 6.5 & 3.5 & 0.45 & 0.70 & 0.27 & 2530 \\
\hline Broiler starter & 23.0 & 4.0 & 3.5 & 1.0 & 0.45 & 1.12 & 0.45 & 2860 \\
\hline Broiler finisher & 19.5 & 3.5 & 3.5 & 0.9 & 0.40 & 1.10 & 0.40 & 3080 \\
\hline Broiler breeder & 16.0 & 3.0 & 5.0 & 3.0 & 0.45 & 0.70 & 0.30 & 2420 \\
\hline
\end{tabular}

Sensitivity Analysis: However, due to conditions such as unstable market prices, post optimality analysis is required to ascertain the effects and economic implications of the price changes on the formulation. While optimal solutions simply provide a best choice of decision variables for one fixing of the input parameters, sensitivity analysis then tries to complete the picture by studying how results would vary with change in parameter values (Arsham, 2009; Rardin ,1998). The constant parameters from which the optimum was derived such as costs, yields, availability and requirements are almost never known with certainty at the time the model is solved. The extent to which these mathematically optimal answers can be trusted to real life imperfectly parameterized models is questionable. For instance, it is a usual occurrence to have seasonal fluctuations in the price of feed ingredients. It is common for the market price of feed ingredients to rise during the rainy season and fall back during the dry season when there is an abundance of dry grains. Hence 
post optimality was carried out on the case study problem.

\section{METHODOLOGY}

The feed formulation model seeks the optimum combination of available feed ingredients that will satisfy the nutritional requirements of the animal at the least cost possible. The model has to satisfy a set of constraints on nutritional levels, availability restrictions, special ingredients to be included, budget or fund constraints. The generic mathematical model which is applicable to each type of ration using the available ingredients is constructed as follows.

\section{The Generic Model}

Notations

Let i: Index identifying feed nutrient components with $\mathrm{i}=1,2, \ldots . \mathrm{m}$

j: index identifying feed components with $j$ $=1,2, \ldots \ldots \ldots . \mathrm{n}$

k: index identifying restricted ingredients with $k=1,2, \ldots \ldots . p$

u: index identifying set of restricted ingredients with $u=1,2, . . q$

$\mathbf{X}_{\mathbf{j}}=$ quantity of feed ingredient $\mathrm{j}$ in the feed mix (decision variable)

$\mathbf{X}_{\mathbf{k}}$ : quantity of restricted feed ingredient $\mathrm{k}$

$\mathbf{N}=$ total quantity $(\mathrm{Kg})$ of feed to be produced

$\mathbf{Z}=$ Total cost of feed ingredients used in the feed formulation

$\mathbf{C}_{\mathrm{j}}=$ unit cost of feed ingredient $\mathrm{j}$

$\mathbf{a}_{\mathrm{ij}}=$ amount (in fraction of $\mathbf{X}_{\mathbf{j}}$ ) of nutrient $\mathrm{i}$ available in feed ingredient $j$

$\mathbf{b i}_{\mathbf{L}}=$ minimum dietary requirement (fraction of $\mathrm{N}$ ) of nutrient $\mathrm{i}$ for a bird category

$\mathbf{b i}_{U}=$ maximum dietary requirement (fraction of $\mathrm{N}$ ) of nutrient $\mathrm{i}$ for a bird category.

$\mathrm{Su}=$ set of restricted ingredients in the feed mix

$\mathbf{L}_{k}=$ lower limit of restricted feed ingredient $k$ in the feed mix

$\mathbf{U}_{\mathbf{k}}=$ upper limit of restricted feed ingredient $k$ in the total feed.

$\mathbf{b}_{\mathbf{k}}$ : proportion of restricted feed ingredient $k$

\section{Objective function}

The objective of this LP model is to minimize total feed costs.

$\operatorname{MinZ}=\sum_{j=1}^{n} C_{j} X_{j}$
Problem constraints: The constraints of the model deal with limitation on the total feed quantity to be produced, nutritional requirements, and nutrients availability in feed ingredients.

The following constraints apply to the feed formulation problem.

1. Feed must meet total demand quantity $\mathrm{N}$ for the planning period.

2. Feed must meet metabolizable energy (ME) and dietary requirement bi for each nutrient.

3. Restricted ingredients must be present in feed within acceptable range

The mathematical equivalent of the above constraint statements are as follows

1. Demand requirement

$$
\sum_{j=1}^{n} X_{j} \geq N
$$

2. Nutrients and energy requirements

$$
b_{i L} \sum_{j=1}^{n} X_{j} \leq \sum_{j=1}^{n} a_{i j} X_{j} \leq b_{i U} \sum_{j=1}^{n} X_{j} \cdots \cdots \forall i=1,2 \cdots m
$$

3. Restricted ingredient levels.

$$
L k \leq X_{k} \leq U_{k} \quad \forall k \in S u
$$

if given in

absolute terms

$$
X k \leq b k \sum_{j=1}^{\text {Or }} X j \quad \forall k \in \mathrm{Su} \quad \text { if } \mathrm{b}_{\mathrm{k}} \text { is a proportion of feed. }
$$

4. Non negativity constraints.

$$
X_{j} \geq 0 \quad j=1,2 \cdots n
$$

The model is summarised as follows

$$
\operatorname{MinZ}=\sum_{j=1}^{n} C_{j} X_{j}
$$

s.t

$$
\begin{aligned}
& \sum_{j=1}^{n} X_{j} \geq N \\
& b_{i L} \sum_{j=1}^{n} X_{j} \leq \sum_{j=1}^{n} a_{i j} X_{j} \leq b_{i U} \sum_{j=1}^{n} X_{j} \cdots \cdots \forall i=1,2 \cdots m \\
& L k \leq X_{k} \leq U_{k} \quad \forall k \in S u \\
& X k \leq b k \sum_{j=1}^{n} X j \quad \forall k \in \mathrm{Su} \\
& X_{j} \geq 0 \quad j=1,2 \cdots n
\end{aligned}
$$


The Layers mash feed formulation Problem: The generic feed formulation model can be adapted to suit any ration and its application demonstrated by layers mash feed ration, with nutrient requirement as indicated in table1. The model has been parameterized by the nutrients yields and costs of locally available feed ingredients summarized in Table 2.

Table 2 Cost implications and nutrient levels of feed ingredients

\begin{tabular}{|l|l|l|l|l|l|l|l|l|l|}
\hline Ingredients & $\begin{array}{l}\text { Price } \\
\mathbf{N} / \mathbf{k g}\end{array}$ & $\begin{array}{l}\text { Crude } \\
\text { protein } \\
\%\end{array}$ & $\begin{array}{l}\text { Energy } \\
\mathbf{M E} \\
\mathbf{k c a l} / \mathbf{k g}\end{array}$ & $\begin{array}{l}\text { Ether } \\
\text { extract } \\
\text { (oil) \% }\end{array}$ & $\begin{array}{l}\text { Crude } \\
\text { fibre } \\
\%\end{array}$ & $\begin{array}{l}\text { Lysine } \\
\%\end{array}$ & $\begin{array}{l}\text { Methionine } \\
\%\end{array}$ & $\begin{array}{l}\text { Calcium } \\
\%\end{array}$ & $\begin{array}{l}\text { Available } \\
\text { phosphorus } \\
\%\end{array}$ \\
\hline $\begin{array}{l}\text { Maize } \\
\text { (yellow) }\end{array}$ & 54 & 10.0 & 3434 & 4.00 & 2.00 & 0.25 & 0.18 & 0.01 & 0.09 \\
$\begin{array}{l}\text { Sorghum } \\
\text { offals }\end{array}$ & 50 & 9.0 & 3300 & 5.00 & 6.0 & 0.25 & 0.18 & 0.10 & 0.09 \\
\hline $\begin{array}{l}\text { soya bean } \\
\text { meal }\end{array}$ & 78 & 45.0 & 2700 & 2.00 & 6.50 & 2.80 & 0.59 & 0.20 & 0.60 \\
\hline $\begin{array}{l}\text { Groundnut } \\
\text { cake }\end{array}$ & 61 & 45.0 & 2640 & 6.00 & 5.00 & 1.60 & 0.48 & 0.20 & 0.20 \\
\hline $\begin{array}{l}\text { palm } \\
\text { kernelmeal }\end{array}$ & 13 & 18.0 & 2175 & 6.00 & 12.0 & 0.64 & 0.39 & 0.21 & 0.16 \\
\hline rice bran & 12 & 12.0 & 2860 & 12.50 & 12.5 & 0.50 & 0.24 & 0.04 & 0.46 \\
\hline bone meal & 33 & - & - & - & - & - & - & 37.00 & 1.50 \\
\hline oyster shell & 12 & - & - & - & - & - & - & 38.00 & - \\
\hline Salt & 40 & - & - & - & - & - & - & - & - \\
\hline Lysine & 420 & 95.0 & - & - & - & 1.0 & - & - & - \\
\hline Methionine & 1140 & 58.0 & - & - & - & - & 1.0 & - & - \\
\hline Premix & 980 & - & - & - & - & - & - & - & - \\
\hline Enzyme & 3000 & - & - & - & - & - & - & - & - \\
\hline
\end{tabular}

The case study farm has the objective of mixing one ton of layers mash during each production cycle at respecting the quantities of feed ingredients are as described in table 3. minimum cost. Thirteen (13) decision variables

\section{Table 3 : List of decision variables}

\begin{tabular}{|l|l|}
\hline $\mathbf{X}_{\mathbf{i}}$ & Variable Description \\
\hline $\mathbf{X}_{1}$ & quantity of yellow maize \\
\hline $\mathbf{X}_{\mathbf{2}}$ & quantity of sorghum \\
\hline $\mathbf{X}_{\mathbf{3}}$ & quantity of soya bean \\
\hline $\mathbf{X}_{\mathbf{4}}$ & quantity of groundnut cake \\
\hline $\mathbf{X}_{\mathbf{5}}$ & quantity of palm kernel cake \\
\hline $\mathbf{X}_{\mathbf{6}}$ & quantity of rice bran \\
\hline $\mathbf{X}_{\mathbf{7}}$ & quantity of bone meal \\
\hline $\mathbf{X}_{\mathbf{8}}$ & quantity of oyster \\
\hline $\mathbf{X}_{\mathbf{9}}$ & quantity of salt \\
\hline $\mathbf{X}_{10}$ & quantity of lysine \\
\hline $\mathbf{X}_{11}$ & quantity of methionine \\
\hline $\mathbf{X}_{12}$ & quantity of premix \\
\hline $\mathbf{X}_{13}$ & quantity of enzyme \\
\hline
\end{tabular}

The summarized model is as stated

Min $Z=54 x_{1}+50 x_{2}+78 x_{3}+61 x_{4}+13 x_{5}+12 x_{6}+33 x_{7}+12 x_{8}+40 x_{9}+420 x_{10}+1140 x_{11}+980 x_{12}+3000 x_{13}$

St.

$\sum_{i=1}^{13} X_{i} \geq 1000 \quad$-for minimum production volume 
$0.10 x_{1}+0.09 x_{2}+0.45 x_{3}+0.45 x_{4}+0.18 x_{5}+0.12 x_{6} \geq 0.165 \sum_{i=1}^{13} X_{i} \quad$ - Protein requirement $0.4 x_{1}+0.5 x_{2}+0.2 x_{3}+0.6 x_{4}+0.6 x_{5}+0.125 x_{6} \geq 0.037 \sum_{i=1}^{13} X_{i} \quad$ - Fat requirement $0.2 x_{1}+0.6 x_{2}+0.65 x_{3}+0.5 x_{4}+0.12 x_{5}+0.125 x_{6} \leq 0.065 \sum_{i=1}^{13} X_{i} \quad$ Fibre requirement $0.0001 x_{1}+0.001 x_{2}+0.002 x_{3}+0.002 x_{4}+0.0021 x_{5}+0.0004 x_{6}+0.37 x_{7}+0.38 x_{8}=0.035 \sum_{i=1}^{13} X_{i}$-Calcium $0.0009 x_{1}+0.0009 x_{2}+0.006 x_{3}+0.002 x_{4}+0.0016 x_{5}+0.0046 x_{6}+0.015 x_{7} \geq 0.045 \sum_{i=1}^{13} X_{i} \quad$ (Phosphorus) $0.0025 x_{1}+0.0025 x_{2}+0.028 x_{3}+0.016 x_{4}+0.0064 x_{5}+0.005 x_{6}+1 x_{10} \geq 0.007 \sum_{i=1}^{13} X_{i} \quad$ (Lysine ) $0.0018 \mathrm{x}_{1}+0.0018 \mathrm{x}_{2}+0.0059 \mathrm{x}_{3}+0.0048 \mathrm{x}_{4}+0.0039 \mathrm{x}_{5}+0.0024 \mathrm{x}_{6}+1 \mathrm{x}_{11} \geq 0.0027 \sum_{i=1}^{13} X_{i}$ (Methionine) $3434 x_{1}+2700 x_{2}+2700 x_{3}+2640 x_{4}+2175 x_{5}+2860 x_{6} \geq 2530 \sum_{i=1}^{13} x_{i} \quad$ (Metabolizable energy)

$\mathrm{X}_{5} \leq 0.25 \sum_{i=1}^{13} X_{i}$

$2.5 \leq X_{9} \leq 3.5$

$\mathrm{X}_{12}=2.5$ (Premix restriction) $\mathrm{X}_{13}=0.1$ Enzyme restriction $X_{i} \geq 0$ for $i=1,2 . .13$

(Palm kernel cake (PKC) restriction)

(Salt level)

RESULTS AND DISCUSSION

Table 4 Existing practice decision Vs Optimal Output of LP Model

\begin{tabular}{|c|c|c|c|c|c|}
\hline Decision variable/ & Obj. Coefficient & Existing $\mathrm{pr}$ & tice & $\begin{array}{l}\text { Proposed } \\
\text { Solution }\end{array}$ & Optimal \\
\hline Feed ingredient $\left(\mathrm{X}_{\mathrm{i}}\right)$ & Cost /Kg (N) & Value $(\mathrm{kg})$ & Cost (N) & Value $(\mathrm{kg})$ & Cost $(\mathrm{N})$ \\
\hline Maize & 54 & 300 & 16200 & 453.62 & 24495.27 \\
\hline Sorghum & 50 & 200 & 10000 & 0.0 & 0.0 \\
\hline Soya & 78 & 150 & 11700 & 0.0 & 0.0 \\
\hline Groundnut cake & 61 & 50 & 3050 & 179.06 & 10922.40 \\
\hline Palm kernel cake & 13 & 100 & 1300 & 200.00 & 2600.00 \\
\hline rice bran & 12 & 70 & 840 & 76.68 & 919.00 \\
\hline bone meal & 33 & 30 & 990 & 20.46 & 675.18 \\
\hline Oyster & 12 & 100 & 1200 & 62.96 & 755.55 \\
\hline Salt & 40 & 3 & 120 & 3.50 & 140.00 \\
\hline Lysine & 420 & 1 & 420 & 1.18 & 497.69 \\
\hline methionine & 1140 & 1.5 & 1710 & 0.04 & 42.46 \\
\hline layer premix & 57.5 & 2.5 & 143.75 & 2.50 & 2450.00 \\
\hline Enzyme & 3000 & 0.1 & 300 & 0.10 & 300.00 \\
\hline \multicolumn{2}{|c|}{ Total/ Objective function value } & & 47973.75 & & 43797.56 \\
\hline
\end{tabular}


The weekly cost of producing layers feed is N47974 using the existing practice of the farm compared with the N43798 if feed formulation is based on the proposed mathematical model. This is a substantial savings of about $9 \%$. Obviously feed formulation is more cost effective when based on valid mathematical programming

The sensitivity analysis results of the feed formulation model are summarized in table 5 while the status of the resources is summarized in table 6 .

Table 5: Output results for sensitivity analysis of the feed formulation model

\begin{tabular}{lrrrr}
\hline Variable & Current Obj Coeff & Min Obj Coeff & Max Obj Coeff & Reduced Cost \\
\hline x1: maize & 54.00 & 44.18 & 56.30 & 0.00 \\
x2: sorghum & 50.00 & 47.98 & infinity & -2.02 \\
x3: soya & 78.00 & 64.95 & infinity & -13.05 \\
x4: GNC & 61.00 & 57.72 & 43.91 & 0.00 \\
x5: PKC & 13.00 & -193.15 & 26.12 & 0.00 \\
x6: rice bran & 12.00 & -82.47 & 547.72 & 0.00 \\
x7: bone meal & 33.00 & 13.08 & 32.45 & 0.00 \\
x8: oyster & 12.00 & -261.82 & 53.01 & 0.00 \\
x9: salt & 40.00 & - infinity & 671.78 & 0.00 \\
x10: lysine & 420.00 & 52.42 & 2263.44 & 0.00 \\
x11: methionine & 1140.00 & 53.97 & infinity & 0.00 \\
x12: premix & 980.00 & - infinity & infinity & 0.00 \\
x13: enzyme & 3000.00 & - infinity & 0.00 \\
\hline
\end{tabular}

\begin{tabular}{|c|c|c|c|c|}
\hline Constraint & Current RHS & Min RHS & Max RHS & Dual Price \\
\hline $1(>)$ & 1000.00 & 347.76 & infinity & 41.23 \\
\hline $2(<)$ & 0.00 & -4.56 & 64.03 & -9.18 \\
\hline $3(>)$ & 0.00 & -infinity & 10.78 & 0.00 \\
\hline $4(>)$ & 0.00 & -6.79 & 21.93 & 145.68 \\
\hline $5(=)$ & 0.00 & -4.35 & 16.06 & 107.93 \\
\hline $6(<)$ & 0.00 & -9.70 & 3.07 & -132.80 \\
\hline $7(<)$ & 0.00 & -11.44 & 1.19 & -366.99 \\
\hline $8(<)$ & 0.00 & -11.44 & 0.04 & -1086.99 \\
\hline $9(>)$ & 0.00 & -infinity & 42641.00 & 0.00 \\
\hline $10(>)$ & 2.50 & -infinity & 3.50 & 0.00 \\
\hline $11(<)$ & 3.50 & 2.50 & 14.94 & -13.01 \\
\hline $12(=)$ & 2.50 & 0.00 & 13.94 & 926.99 \\
\hline $13(=)$ & 0.10 & 0.00 & 11.54 & 2946.99 \\
\hline $14(>)$ & 0.00 & -50.14 & 250.00 & 24.61 \\
\hline
\end{tabular}

It can be observed that the dual or marginal prices of the surplus resources (fat, energy and salt) are zero. Which implies that there is no economic advantage in allocating more of that resource, while a unit increase in the other resources will lead to a corresponding increase in the objective value to the tune of the dual price. For instance, a unit increase in the total quantity of feed produced will increase the objective value by $\mathrm{N} 41.23$ within the stated range $347.76 \leq$ RHS $\leq \infty$. However, it is important to note that the dual prices will remain applicable for simultaneous changes that keep the solution feasible, even if the changes violate the individual ranges (Taha, 2007).
Note that outside the price ranges given for the objective function coefficients the optimal solution ceases to be valid. For maize, the range of objective coefficients within which the optimal solution remains valid is $[44.18,56.30]$, the optimal quantity for maize is $453.62 \mathrm{~kg}$, thus for every $\mathrm{N} 1$ increase in the objective function coefficient, there is a corresponding increase of $\mathrm{N} 453.62$ within this range. This interpretation applies to the other variables.

\section{CONCLUSIONS}

Controlling feed costs is critical to the sustainability of the Nigerian poultry Industry. This paper has demonstrated how the application of a linear 
programming approach to feed formulation will lead to higher productivity in this sector as opposed to the use of relatively inefficient methods such as the trial and error method. Approximately nine percent $(9 \%)$ reduction in costs were made with the implementation of the new method.

This model has been adapted to the Nigerian environment taking into account the locally available feed ingredients and improving on the existing methods prevalent in the Nigerian poultry industry.

The general model can be extended to tackle other types of feed formulation, although this study has focused on layer's mash, the model can easily be adapted to suit other types of rations.

Lastly, this study has illustrated the use of sensitivity analysis, a powerful and versatile tool for analyzing the impact of the changes in parameters that is indicative of problematic conditions such as unstable market prices and nutrient variations prevalent in the Nigerian poultry industry. However, with increasing interest in quality assurance procedures, it is envisaged that the problem of nutrient variability will receive a considerable amount of attention in the very near future.

\section{REFRENCES}

1. Adebayo, O.O. and R.G. Adeola, 2005. SocioEconomic Factors Affecting Poultry Farmers in Ejigbo Local Government Area of Osun State. J. Hum. Ecol., 18(1): 39-41

2. Afolayan, M.O. and M. Afolayan, 2008. Nigeria Oriented Poultry Feed Formulation Software Requirements. J.of Applied Sciences Research, 4(11): 1596-1602

3. Alimon, A.R. and M. Hair-Bejo, 1995. Feeding systems based on oil palm by-products in Malaysia. In: Proceedings of the First Symposium on the Integration of Livestock to Oil palm production. Kuala Lumpur, Malaysia, 105-113.
4. Arsham, H., 2009 Deterministic Modeling: Linear Optimization with Applications available at http://home.ubalt.edu/ntsbarsh/opre640a/partviii.htm\# rcotdp

5. Castrodeza, C., P. Lara, and T. Pena, 2005. A Multicriteria fractional model for feed formulation: economic, nutritional and environmental criteria. Agricultural Systems 86 76-96

6. Dogan, I., N. Dogan, A. Akcan, 2000. Using goal programming in rational and economical animal nutrition. Turk J Vet Anim Sci 24: 233-238.

7. Fanatico, A., 2010. Organic Poultry Production: Providing Adequate Methionine. ATTRA Publication IP363/363. $<$ http://attra.ncat.org/attrapub/methionine.html

8. Labier, M., and B. Leclercq, 1994. Nutrition and feeding of poultry. Nottingham University Press, Loughborough, Leicestershire, England.

9. Longe, O.G., 1984. Effects of increasing the fibre content of a layer diet. Brit. Poult. Sci. 25:187-193.

10. Moreson Nigeria Ltd, 1988. Feed formulation Guide, Publications of Moreson Nig. Ltd. Ikeja, Lagos

11. Okonkwo, W.I., and C.O. Akubuo, 2001. Thermal analysis and evaluation of heat requirement of a passive solar energy poultry chick brooder in Nigeria. $\mathrm{J}$ of Renewable Energy, 9: 1

12. Olorunfemi, T.O.S., 2007. Linear programming approach to least-cost rations formulation for poultry. Information Technology Journal 6 294-299.

13. Rardin, R.L., 1998. Optimization in Operations Research. Prentice Hall

14. Sahman, M.A., M. Cunkas, S. Inal , F. Inal, B. Coskun, and U. Taskiran, 2009. Cost optimization of feed mixes by genetic algorithms. Advances in Engineering Software 40 965-974

15. Samuel, E.J.J., K.S.P. Duraira, and S. Mohan, 2002. For the detection of aflatoxin in groundnut (arachis hyposaea I. Kernels). Asian J. Chem. 14:874-878.

16. Scheideler S.E., 2008. Trace mineral balance in poultry Available <http://www.zootecnicainternational.com/articlearchive/nutrition/284-trace-mineral-balance-inpoultry.html>

17. Taha, H.A.,2007. Operations Research: an introduction. $8^{\text {th }}$ ed. Pearson Education, Inc., USA 